\title{
On the Path of Ideological and Political Construction of College Curriculum
}

\author{
Xiaoling $\mathrm{Wu}^{1}$ \\ ${ }^{1}$ Fuzhou Preschool Education College, Fuzhou, Jiangxi, 344000 \\ 739960103@qq.com

\begin{abstract}
After sorting out and analyzing the importance, practicability and current situation of the construction of "curriculum ideological and political" in Colleges and universities in the new era, we find that the following five aspects are good entry points for the construction of "curriculum ideological and political" in Colleges and universities in the new era: clarifying the goal framework of Ideological and political work, coordinating and advancing the construction of "curriculum ideological and political", strengthening the construction of "curriculum ideological and political" teachers, and highlighting the teaching content Rong's "Ideological and political" role and to create a unique campus culture.
\end{abstract}

Keywords: new era; curriculum, ideological and political education, construction path

\section{论高校课程思政建设的路径}

\author{
伍小玲 1
}

\author{
${ }^{1}$ 抚州幼儿师范高等专科学校 江西 抚州 344000 \\ 739960103@qq.com
}

摘要:

整理分析新时代高校 “课程思政” 建设的重要性、实用性以及研讨现状后，我们发现，新时代下，以下五个方 面是高校 “课程思政” 建设很好的切入点：明晰思想政治工作目标框架、协调共进 “课程思政” 建设、强化 “课程思政”师资建设、突出课程教学内容的“思政”作用以及打造独具的校园文化。

关键词: 新时代; 课程思政; 建设路径

\section{1.新时代高校“课程思政”建设的必要性}

学校思想政治教育平台的“课程思政”充分探索 出了高校在所开设的各类人文社科通识课程、专业开 设的课程中，各种隐性与显性的思想政治教育资源， 进而起到与思想政治理论课育人目标——立德树人 的教育理念相互一致、相互协调的作用。

2016 年 10 月,在北京举行的全国高校思想政治工 作会议上, 习近平总书记强调:“要用好课堂教学这个 主渠道,思想政治理论课要坚持在改进中加强,提升思 想政治教育亲和力和针对性, 满足学生成长发展需求 和期待,其他各门课都要守好一段渠、种好责任田,使 各类课程与思想政治理论课同向同行,形成协同效应。 现阶段, 一个误区一一学生的职责所在是学习好专业 知识也技术职能, 这也是专业课程设立的根本目的, 而思想政治理论课的“主战场”是思想政治教育者的
工作，是思想政治理论课教师的应该考虑的事情，在 部分高校很普遍地存在。这一“误区”不可避免地会导 致的一个不良后果就是出现思想政治理论课与通识 课程、专业课程互相分离、各不相干,高校的育人的效 果会受到很大影响。在此误区下，怎样顺应新时代、 新要求是一个值得思考的问题。笔者认为, 首先是肯 定在青少年茁壮成长过程中思想政治理论课中起到 了一系列效用, 例如, 树立他们的精神信仰、塑造他 们的优良品质、将道德化生活方式融入到他们的生活, 除此之外, 还要不断推进和探索新的通识课程、专业 课程的思想政治教育资源。其次要将“课程思政”教育 教学改革思想让全体通识课程与专业课程的任课教 师深刻于心,将隐形思想政治教育资源充分利用起来, 包含并融入到课程设立、课堂授学和实习实践的各个 阶段中,进而满足时代发展的需要,适应时代发展的要 求,构建优良的“课程思政”运行机制,将思想政治教育 工作穿插于大学生成长成才的方方面面,开拓育人创 
新的新局面。

\section{2 新时代高校“课程思政”建设的现实意义}

中国共产党提出我国社会发展的历史新方位是 中国特色社会主义进入了新时代。从新中国成立、再 到改革开放，中华民族从“站起来、富起来再到强起 来”, 实现了历史性的飞跃。但是居安思危, 我们要正 视中国社会正处于矛盾凸显的转型期这一现状，更应 该认识到当下一些深层次的问题亟于解决。“面对社 会变化所带来的矛盾和冲突, 教育者应以知识分子的 责任感维护在市场原教旨主义冲击下日益萎缩的社 会价值观和公民道德。青年是国家的希望, 在新时代 背景下, 立德育人、为民族复兴提供人才后备军的重 任肩负践行在各大高校肩上，肩负于教育工作者身上, 这也是他们应有的责任与担当。

当然，由于思想政治教育是一个庞大的系统，除 了国家宏观的设计安排外, 但也需要其他措施相互配 套, 这也离不开一线教育工作者的投身参与。并且在 课程设立上要统筹各类课程、破除课程与课程之间、 学科与学科之间的界限, 将课程思政的功效发挥出来。 在教学过程中, 要将思想政治教育隐性与显性的资源 融入到有厚度的专业知识中, 从而使学生能够在学识、 能力与素养的全面发展。我国现处于全面建成小康社 会的决胜阶段, 中国特色社会主义进入了新时代开启 新征程, “共耕”培养和造就大批合格建设者和接班人 的责任田是高校责无旁贷的责任, 高校需要创新“课 程思政”教育理念, 寻求和探索搭建全员、全过程、全 方位育人的大思政平台切实有效的措施。

\section{3 新时代高校“课程思政”建设的现状研究}

我们通过统观研究现阶段各地学校“课程思政” 建设的现状, 得出了以下结论: 首先是从高校各专业 课程的思想建设研究来看, 高校们对其研讨很少。缺 少政治敏锐性是很多专业课程教师的“通病”，他们陷 入一个误区一一将搞好自己的专业教学、专业建设作 为研究教学的全部内容, 没有把课程思政建设与日常 教学相协调的创新意识, 当然我们不能以偏概全, 还 是存在专业课程教师进行思政教育融入日常专业教 学的尝试, 但是虽有研究, 也不是针对所有的课程开 展思政的研究, 成果碎片化; 其次是在探索专业课中 思政元素的教育资源方面, 专业课老师的研究很少触 及, 此现象的出现主要是对“全员育人、全程育人和全 方位育人”思想的内涵与精髓, 没有一个很好地掌握。 虽然有关报告、文件对“课程思政”的建设一次次强调， 但是一个很“致命”的现状就是专业理论知识和技能 的传授与学生专业素质提升与职业素养各自为政, 未 能将学生提高能力与素质融入到理论知识的传授中, 仅将“育人”作为学校思想政治工作者的奋斗目标, 直 于此种观念, 大多数学校专业课程的“课程思政”建设 没有起到作用, 仅停留在表面; 最后是思政课教师并 不了解专业群的构建, 也不熟悉专业课程的框架体系,
尤其是对学生的专业顶岗实习、专业教育与职业精神 培育研究比较少, 因此, 在如何把“思政课程”与“课程 思政”二者整合资源、融入思想政治教育方面的资源 量少、面窄，未能有效地统揽思政课与专业课的有机 融合。基于此上种种, “课程思政”的课程研究是十分 必要的。

\section{4 新时代高校“课程思政”建设的路径探究}

新时代下，在“课程思政”的研究方面，全国各高 校积极参与也收获了较好的成果。但虽然都是对“课 程思政”进行研究，各高校的侧重点不同，其中“课程 思政”改革是大多数高校研究和探讨的重点, 将高校 “课程思政”建设运用于具体的实践中，还存在推进探 讨的空间。因此，笔者认为要将“课程思政”建设理论 运用到实践中, 发挥它的实用价值, 可以从以下五个 层面, 进行探究。

\section{1 提高政治站位, 明确思想政治工作目标体 系}

思想政治工作在当今新时代背景下受到了各大 高校十足的重视，历经多年的办学实践，他们摸索出 了符合自身特点的工作优势和特色新方法。党的十八 大召开后，有关全国高校思想政治的工作会议和全国 教育的会议陆续召开, 在此基础上, 在课程思政建设 理念中, 习近平新思想和党的十九大精神得到了更加 深入贯彻和落实, 在学校内部质量教学改革与诊断建 设项目辅助下, 高校开展育人教学诊断的工程; 以立 德树人的高度责任感为基点, 各校党委不断完善育人 体制机制建设; 通过强化对意识形态的管控、加大校 园宣传引导教育, 在“智慧校园”建设和易班建设的背 景下, , 打造具有独具特色、朝气蓬勃校园文化; 为发 挥全体教师的带头模范作用, 进一步推进对他们师德 师风的考核; 服务于学生的成长离不开“三风”建设、 诚信教育工作以及践行党的十九大精神社会实践活 动的开展等, 为实现“两个百年”目标提供骨干力量。

\section{2 搞好顶层设计，协调推进“课程思政”建设}

为实施“三大工程”建设，即教师思想政治素质提 升、大学生思想政治教育推进和基层党组织建设, 国 家宏观层面有关加强和改进新形势下思想政治工作 实施意见陆续出台, 学校“大思政”工作格局增加了一 项为“课程思政”, 统筹规划, 协调推进。不断加强师 资队伍的思政教育, 将专业课教师变成思政建设的另 一载体, 让思政教育队伍成为课程思政的队伍建设的 又一力量, 积极探索专业理论课程中的思政元素, 为 丰富思政教育的内容和方法, 恰当地纳入专业课堂和 实训环节，构建“三全”体系协同育人，培育卓越的职 业人。佐以自上而下因素的设计理念, 推动学校转变 全员全课程全时空的育人思政教育观念, 完善思政课 程建设的体制机制; 集体备课制度——思政教师与各 教学系跨界一起备课, 有利于探索专业课和实训课程 
里思政元素的教育资源，进而将思政教育融入其中; 借助专业/行业, 以优秀职业人培养为基点, 创新思政 教育的方法, 存在于专业课程中的职业道德、职业精 神、专业发展史和英雄人物等思政资源, 也是挖掘思 政教育内容的另一路径，构建“三全”参与的育人方式， 提升思政教育的实际效果。

\section{3 深化改革创新，强化“课程思政”特色专业 群建设}

除了一般专业的设置, 可以推进开设具有特色的 专业课程, 创新授学方法, 构建“实训、竞赛和创新” 三位一体的大平台。首先是跟进领域和地方发展的要 求, 建设一流专业群。与地方建设发展相契合、满足 他们的发展需求, 进而寻找所需开设的特色专业群, 以此为重点, 对接到现地方行业的需求中; 以一定的 行业标准对地方人才提出要求, 构建和完善新的人才 结构。其次是不要局限与一种或几种单一的办学授课 模式, 要不断创新, 开发多种专业人才培养模式, 将 道德品质、行业精神、工匠精神和特色文化纳入专业 人才培养之中。搭建体系性课程平台, 如通识课平台、 专业+创新（行业、工匠精神）平台。依托校企文化进 行育人教育, 将理论与实践相结合, 学校与企业协同 共同建设工作中心、培育创新技术人才。再次是以满 足产业需求为出发点, 创新出适应其专业教学的方式 方法。以产业市场的实际需求标准出发, 将行业中的 生产标准、所遇到的技术问题等纳入到学校的专业课 程教学中, 除此之外, 结合互联网发展, 打造以慕课 为主干的多种教学方式改革、打造优质在线开放课程, 共享教育资源, 做到资源配置的最优化, 贯通技能竞 赛、专业课堂与技术创新等等。最后是为培育实用性 人才、鼓励在校学生创新创业、搭建“训赛创”全方位 的平台。将理论与实践相结合、各专业学生可以利用 其在专业课程中的所学所思, 通过创业大赛的形式, 表现出来, 除了大赛这一种方式, 在日常教学中, 教 育者也可以布置课后练习、学校构建专业实训基地, 把这些建设成为“实训、竞赛、创新”一体化综合平台, 激发创造力潜能, 鼓励创业, 再利用各种资源扩建大 学生创业园, 开展多方位、多方式的创新实践活动。

\section{4 坚持专业教学与校园文化相结合, 开发独 具特色的校园文化}

培育独具特色的校园文化, 加强与企业文化融合, 将文化融入到专业课程教学中。一是借助互联网开通 的微信公众订阅号等新媒体手段, 大力宣传校园文化。 其次是紧跟发展时事, 利用“互联网+”信息技术手段, 开发精品在线开放课程建设, 多途径推进校园文化建 设。三是通过校园环境规划, 建造一些具有校园特色 的标志性建筑物, 例如教学楼、操场、广场、校园小 卖部、林荫小道和学生宿舍等, 打造独具校园文化的 品牌特色, 营造浓厚的校园育人文化环境氛围、耳濡 目染、不知不自觉中实现心灵育人。四是开设有关“职
业榜样”和“杰出校友”主题的座谈会、报告会, 邀请优 秀杰出校友作为主讲人、诉说他们与学校的“传奇故 事”, 发挥优秀校友的模范作用。校内生活与社会实践 经历联动, 尽早培育学生们的职业精神, 除此之外还 可以加设全校规模的评选活动, 形成比学赶帮的优良 校园氛围。五是扩充校园文化建设的内涵, 校园文化 不仅限于如上所述, 还可以把所在地方的公司文化、 社区文化融进校园，把各校的区位优势利用起来，打 造大学生实践研究室; 就校内企业文化的宣传, 可以 邀请当地一些知名企业家在校开展座谈会、宣讲会, 开设有关校园文化的选修课程, 将校园文化纳入专业 学习中, 构建具有地方特色的文化体系, 立志培养更 多符合领域实践中需要的技术人才。

\section{5 结论:}

新时代下，依托着地理优势、授学特色，全面、 多途径探究“课程思政”建设路径, 全国高校更加注重 理论课程与思想政治教育相结合，打造了独具特色的 “课程思政”品牌，效果显著，达到预期目标。为新时 代背景下的专业教育提供了一个无缝对接的平台, 发 挥“课程思政”应有的功效，“立德树人”，培育出一代 又一代实现“两个一百年”目标的建设者和“伟大复兴” 事业的接班人。

\section{REFERENCES}

[1] Xi Jinping stressed at the National Conference on Ideological and political work in Colleges and Universities: the ideological and political work runs through the whole process of education and teaching to create a new prospect for the development of higher education in China, $[\mathrm{N}]$. people's daily, 2016-12-09 (1).

[2] [America] Andy Hargreaves. Education in knowledge society $[\mathrm{M}]$. Shanghai: East China Normal University Press, 2007:13-20

[3] Wen Ya, song Suhua, Zhang Qinyuan, Wang Honghai, Qu Yi. Exploration and practice of Integrating Ideological and political education into multi dimensional classroom teaching of treatise on febrile diseases [J]. Journal of traditional Chinese medicine, 2020,26 (8): 105107

[4] Li Xiping. Discussion on the integration of Ideological and political education into Higher Vocational Pharmacy Teaching -- Taking the integration of Ideological and political education in the classroom of pharmaceutical regulations as an example [J]. Journal of Yueyang Polytechnic, 2009,24 (5): 81-83

[5] Wang Lu. Evaluation and experience reference of typical innovative development models of 
Foreign Ideological and Political Education [J]. Journal of Bohai University: Philosophy and Social Sciences Edition, 2012 (4): 118-122

[6] Zhang Ying. Research on the path of Higher Vocational Professional Curriculum Construction Based on the new concept of curriculum ideology and Politics -- Taking the course of consumer psychology in Jilin Vocational College of engineering as an example [J]. Intelligence, 2019,0 (28): 9-9

[7] Zhang Xue. Generation mechanism and practical exploration of the effectiveness of Ideological and political work in Higher Vocational Colleges in the new era -- Taking Chengdu industry and Trade Vocational and Technical College as an example [J]. Journal of Sichuan cadre correspondence college, 2019,0 (2): 71-74

[8] Shi Jinna, Hao Fuhong, Li Yuanchen. Practical research on the integration mode of Ideological and political education in engineering courses -Taking the course of introduction to civil engineering disaster prevention and reduction as an example $[\mathrm{J}]$. Journal of higher education, 2019,0 (20): 99-101

[9] Hou saining, Gu Yingchun, Ma Qiong, Guan Lili, Zhang Min, Wang Xiaojun. Exploration on teaching reform of community nursing course in Higher Vocational Colleges from the new perspective of "Curriculum Ideology and politics" [J]. Modern education forum, 2019,2 (9): 14-15

[10] Chen Jin. On the ideological and political reform of hotel management major in Higher Vocational Colleges in the new era -- Taking the course of front office operation and management as an example [J]. Journal of Yan'an Polytechnic, 2020,34 (2): 44-46

[11] Zhang Yiyi, Li Xiaopei. Exploration and practice of higher vocational curriculum reform from the perspective of curriculum ideology and Politics -Taking auditing practice course as an example [J]. Journal of Taiyuan City Polytechnic, 2020 (9): $133-137$

[12] Shi Jinyan, Gong Huanghui, Zhang Kechang, Dong Xiaoying. Research on the current situation and improvement path of Ideological and political education in Higher Vocational Colleges -- Taking Zhuzhou City as an example [J]. Science and technology vision, 2020 (23): 87-89

[13] Meng Lin, Huang Yuzhong, Miao Wei, pan Tangjun. Research on the path of realizing "curriculum ideological and political education" in Independent Colleges from the perspective of curriculum integration $[\mathrm{J}]$. New West, 2020 (18): 173-174

[14] Zhou Wenjiao, Xu Fengfeng, Jiang Bingying, Li Shuo. Preliminary exploration and practice of natural integration of Ideological and political education and modern instrumental analysis [J]. Guangdong chemical industry, 2020,47 (19): 232233

[15] Wu Ren Tu ya, La Xi Na Mu Ji La, Wang Xiu LAN, Wang Huan, Hu Yi Li Ge Qi, Wu Long Tang. Discussion on Integrating Ideological and political education into the teaching mode of Mongolian pharmacology [J]. Curriculum education research, 2019,0 (43): 243-243 